https://doi.org/10.17816/MAJ191S144-45

\title{
THE GABA-ERGIC SYSTEM DOES NOT CONTROL THE NOCICEPTIVE RESPONSES OF PRIMARY SENSORY NEURON
}

\author{
V.A. Penniyaynen, S.A. Podzorova, S.G. Terekhin, B.V. Krylov, V.B. Plakhova \\ Pavlov Institute of Physiology of the Russian Academy of Sciences, Saint Petersburg, Russia

\section{ГАМК-ЕРГИЧЕСКАЯ СИСТЕМА НЕ КОНТРОЛИРУЕТ НОЦИЦЕПТИВНЫЕ ОТВЕТЫ В ПЕРВИЧНОМ СЕНСОРНОМ НЕЙРОНЕ}

\author{
В.А. Пеннияйнен, С.А. Подзорова, С.Г. Терехин, Б.В. Крылов, В.Б. Плахова
}

ГБУН «Институт физиологии им. И.П. Павлова» РАН, Санкт-Петербург

The aim of the study was to elucidate the molecular mechanisms of the interconnection of the GABA-ergic and nociceptive systems at the level of the peripheral division of the CNS. The data obtained indicate that GABA does not affect the activation gating device of the $\mathrm{Na}_{\mathrm{v}} 1.8$ channel of the primary sensory neuron responsible for coding pain signals. This agent in a wide range of concentrations also does not affect the growth of neurites of sensory neurons of embryonic nervous tissue. These results confirm our assumption, expressed earlier that the asynaptic membrane of the primary nociceptive neuron is not under the control of the GABA-ergic system.

Keywords: GABA; $\mathrm{Na}_{\mathrm{v}} 1.8$ channels; nociception.

Целью исследования явилось выяснение молекулярных механизмов взаимосвязи ГАМК-ергической и ноцицептивной систем на уровне периферического отдела ЦНС. Полученные результаты указывают на то, что ГАМК не влияет на активационное воротное устройство каналов $\mathrm{Na}_{\mathrm{v}} 1.8$ мембраны первичного сенсорного нейрона, ответственных за кодирование болевых сигналов. Этот агент в широком диапазоне концентраций также не влияет на рост нейритов сенсорных нейронов эмбриональной нервной ткани. Полученные результаты подтверждают наше предположение, высказанное ранее о том, что асиноптическая мембрана первичного ноцицептивного нейрона не находится под контролем ГАМК-ергической системы.

Ключевые слова: ГАМК; каналы $\mathrm{Na}_{\mathrm{v}} 1.8$; ноцицепция.

Introduction. As a well-known inhibitory neurotransmitter in the central nervous system, gamma-aminobutyric acid (GABA) also has critical roles in immune system. Immune cells express the components of GABA-ergic system, including GABA receptors, GABA transporters, and GABA metabolic enzymes. Despite the uniqueness and great physiological significance of the GABA-ergic system, the molecular mechanisms of its influence on the peripheral part of the nociceptive system remain insufficiently studied. This gap can be eliminated by studying the effects of modulation of the channel $\mathrm{Na}_{\mathrm{V}} 1.8$ by GABA. $\mathrm{Na}_{\mathrm{V}} 1.8$ channels control nociceptive information transmitted to the central nervous system. It is known that agents that are capable of reducing the excitability of nociceptors by reducing the voltage-sensitivity of the activation gating device of the $\mathrm{Na}_{\mathrm{V}} 1.8$ channels can claim to be analgesic drug substances [1]. We have obtained data indicating a possible mechanism underlying the relationship between the GABA-ergic and nociceptive systems [2]. The aim of this article is to attempt to detail this mechanism.

Material and methods. The effect of GABA on the growth of dorsal root ganglion (DRG) neurites was investigated using the organotypic tissue culture method, as described in detail in our previous article [3]. Experiments were conducted using the equipment of the Confocal Microscopy Collective Use Center at Pavlov Institute of Physiology RAS. The area index (AI) was calculated as the ratio of the explant growth area to the area of the central zone of a ganglion. The AI value of control explants was taken for $100 \%$.

Patch-clamp whole-cell experiments allowed to investigate the voltage-sensitivity of nociceptive membrane as it was described earlier [1, 3]. The culture of dissociated DRG sensory neurons isolated from the L5 - S1 domains of newborn Wistar rats makes it possible to study the effect of GABA on $\mathrm{Na}_{\mathrm{V}} 1.8$ channels. The animals were obtained from the Biocollection of I.P. Pavlov Institute of Physiology.

Statistical analysis. The data were analyzed with STATISTICA 10.0 and expressed as the mean value \pm standard error of the mean. Statistical significance was set at $p<0.05$.

Results and discussion. After three days of culturing, two distinct zones can be recognized in the sensory ganglia explants. We emphasize that there are no synaptic connections yet. GABA demonstrated no influence on embryonic nerve tissue growth in the wide range of concentrations from $1 \mathrm{nM}$ to $1 \mathrm{mM}$. It can be concluded that the asynaptic membrane of the primary sensory neu- 
ron does not involve metabotropic GABA receptors $\left(\mathrm{GABA}_{\mathrm{B}}\right)$ that might participate in intracellular cascade processes that regulate the growth of neurites.

The behavior of the activation gating device of the $\mathrm{Na}_{\mathrm{V}} 1.8$ channels in response to the GABA applications was investigated using the Almers' method [1]. It is shown that the application of GABA from the outer side of the sensory neuron membrane at a concentration of $100 \mathrm{nM}$ and $1 \mu \mathrm{M}$ did not change the value of effective charge $\left(Z_{\text {eff }}\right)$ of the activation gating system of the $\mathrm{Na}_{\mathrm{V}} 1.8$ channels: $Z_{\text {eff }}=6.5 \pm 0.3(n=19$, control data), and $6.3 \pm 0.3$ $(n=22)$, after $100 \mathrm{nM}$ GABA application, and $6.4 \pm 0.3(n=25)$ after $1 \mu \mathrm{M}$ GABA application.

The fact that GABA is a universal CNS inhibitory agent makes it necessary to look for its influ- ence on the nociceptive system, since effective and safe analgesics are currently absent in the arsenal of practical medicine. The interaction between the GABA-ergic and nociceptive systems exists, but it appears, probably, at the level of the secondary neuron, where the synaptic transmission is realized. The data obtained confirm this hypothesis, which we expressed earlier [2]: the asynaptic membrane of primary nociceptive neurons is not controlled by the GABA-ergic system.

Acknowledgments. The present work was funded by the Russian Foundation for Basic Research, project No. 18-015-00071. The studies were financially supported by the Program of Fundamental Scientific Research in State Academies for 2014-2020 (SP-14, section 64).

\section{References}

1. Krylov BV, Rogachevskii IV, Shelykh TN, Plakhova VB. New non-opioid analgesics: understanding molecular mechanisms on the basis of patch-clamp and quantum-chemical studies. Sharjah: Bentham sci. publ. Frontiers in pain sci. 2017;1:203.

2. Tyurenkov IN, Perfilova VN, Vasil'eva OS, et al. GABA-and NO-ergic modulators control antinociceptive responses. Activitas nerv. super. Rediviva. 2018;60(1):1-8.

3. Penniyaynen VA, Plakhova VB, Rogachevskii IV, Krylov BV. Src kinase is involved in comenic acidtriggered signaling pathways in sensory neurons. Activitas nerv. super. Rediviva. 2018;60(1):19-27. 